\title{
Does a Placebo Run-In or a Placebo Treatment Cell Affect the Efficacy of Antidepressant Medications?
}

\author{
Madhukar H. Trivedi, M.D., and John Rush, M.D.
}

During the last decade, there has been an increasing use of a placebo run-in period prior to randomization to active treatments, or placebo in randomized controlled trials aimed at establishing acute phase antidepressant drug efficacy in patients with major depression. This procedure is thought to reduce response rates to placebo treatment after randomization, thereby increasing the drug-placebo difference. Metaanalyses of 101 studies reveal that a placebo run-in does not (1) lower the placebo response rate, (2) increase the drug-placebo difference, or (3) affect the drug response rate post-randomization in either inpatients or outpatients for any antidepressant drug group. If there is a post-randomization placebo treatment cell, drug response rates are unchanged or are slightly lower than if there is no placebo treatment cell for outpatients. These results suggest that a pill placebo runin provides no advantage in acute phase efficacy trials. [Neuropsychopharmacology 11:33-43, 1994]
KEY WORDS: Depression; Placebo; Metaanalysis; Placebo run-in; Antidepressant medication

The placebo run-in phase has become virtually standard practice in randomized controlled trials (RCTs) to test the efficacy of antidepressant medications in phase III and often phase IV studies. This single-blind phase usually lasts $3-14$ days, followed by patients being randomized to treatment. However, if patients show a meaningful symptomatic reduction (usually defined as a $20 \%$ to $25 \%$ improvement on a symptom rating scale), subjects are excluded from study. The implications of this practice have rarely been empirically evaluated.

The rationale, based largely on intuition, is thought to reduce placebo responders post-randomization, thereby lowering post-randomization placebo response rates, and increasing differences between placebo and active treatments. Prien and Levine (1984) also sug-

From the Mental Health Clinical Research Center and Department of Psychiatry, University of Texas Southwestern Medical Center, Dallas, Texas.

Address reprint requests to: Madhukar H. Trivedi, M.D., MHCRC at St. Paul POB I, 5959 Harry Hines Blvd., Suite 600, Dallas, Texas 75235-9101.

Received November 30, 1993; accepted March 2, 1994. gested that the placebo run-in might eliminate rapid remitters, thereby reducing the need for post-randomization placebo control treatment in some circumstances.

The insufficient empirical data amassed to test these notions have not strongly supported the practice. Reimherr et al. (1989), in a retrospective reanalysis, discovered that the elimination of prerandomization placebo run-in "responders" reduced the drug-placebo difference from $30 \%$ to $25 \%$ in outpatients with major depression, and surprisingly, increased the placebo treatment response rates from $13 \%$ to $16 \%$.

Additional circumstantial data to question the value of this practice is from adult trials that have attempted to clinically characterize placebo responders. Outpatients who "respond" during the placebo run-in tend to have longer episodes, a more chronic illness, a lower initial level of symptom severity, and are more likely nonendogenous. In comparison, patients who respond to placebo after randomization, tend to have shorter current episodes and higher symptom severity at randomization (Fairchild et al. 1986; Rabkin et al. 1986, 1987). These findings, albeit from different studies, hint that those who "respond" to a placebo run-in may not be isomorphic with those who ultimately respond to postrandomization placebo treatment. 


\section{METHODS}

\section{Selection of Studies}

This report is based on literature identified and tabulated for a larger review, commissioned by the Agency for Health Care Policy and Research (Depression Guideline Panel 1993). All relevant English language, peerreviewed, randomized controlled acute phase treatment trials for inpatients and outpatients with major depression were included (see Depression Guideline Panel in press). The search, conducted by the National Library of Medicine, used MEDLINE and Psychological Abstracts. Key search words included generic names of all antidepressant medications. Abstracts were obtained and reviewed for all acute phase RCTs from 1975 to 1990 (except for monoamine oxidase inhibitors [MAOIs] from which literature from 1959 to 1990 was used).

Articles that met the following inclusion/exclusion criteria were selected: (1) written in English; (2) patients had major depressive or bipolar disorder; (3) the trial had to last three weeks; (4) a quantitative outcome measure was used; (5) a comparison was made between a known antidepressant drug and a placebo, another medication, or both; and (6) the study was blinded. A total of 141 eligible, placebo-controlled RCTs were identified, of which 101 could be metaanalyzed.

Evidence tables were created to summarize the author's report of either the percentage of responders in each cell or the percentage of responders betweencell differences. The numbers randomized, responding to, and completing each treatment cell were recorded (Depression Guideline Panel, in press).

\section{Assessment of Outcome}

For this report, we focused on studies providing dichotomous outcome measures. Categorical scoring was chosen because it addresses the question most patients want to know. How likely am I to get better if I follow treatment? In addition, categorical data was required for the metaanalytic procedures.

In nearly all studies, outcome was based either on the Hamilton Rating Scale for Depression (HRS-D) (Hamilton 1960) or the Clinical Global Impression (Guy 1976). Virtually every study that used the HRS-D counted a $50 \%$ reduction in the HRS-D score as a responder. If the HRS-D was not reported, then a CGI response of 1 or 2 (markedly improved, or very much improved) was counted.

\section{Determination of Success Rates}

The success of a treatment may be reported in three different ways. First, an "intent-to-treat" analysis, that utilizes all patients who improved (regardless if they remained in the study) as the numerator, and the number randomized to treatment as the denominator, addresses the question of how many patients randomized to the treatment improve. Second, an "adequate treatment" analysis includes only patients who received a predetermined minimum amount of treatment (typically 2-4 weeks for medication) as the denominator, and counts those that responded as the numerator. This approach answers the question of how many improve from receiving at least the minimal amount of treatment thought to be effective. Finally, a "completer" analysis includes only those who completed the full protocol. The numerator and denominator include only these patients.

These three methods produce different responses rates. Assume that 100 patients are randomized to treatment, 80 complete 3 weeks (defined a priori as "adequate treatment"), and 40 complete the treatment (e.g., 8 weeks). Assume an adequate course of treatment is $75 \%$ effective, a full course is $95 \%$ effective, and for simplicity, patients who withdraw from treatment do not improve. Completer response rate is 0.95 (40/40) or $95 \%$. The adequate treatment response rate is $0.75(40)$ plus $0.95(40 / 80)$ or $78 \%$. The intent-to-treat response rate is $0.95(40 / 100)$ or $38 \%$. Thus, success rates range from $38 \%$ to $95 \%$ depending on the sample chosen.

We used modified intent-to-treat analysis for this report. The denominator for this analysis was the number of patients randomized to each treatment cell. The numerator was the number of patients who improved while in treatment. This modification was required because very few studies followed patients after they left the trial. If some patients who left a study improved anyway (which is possible), the modified intent-to-treat response rates will be lower than a true intent-to-treat analysis. However, the between-treatment comparisons, based on the modified intent-to-treat analysis should generally be similar to those using a true intentto-treat analysis because response rates in subjects leaving the study are not expected to differ across treatments.

\section{Method of Metaanalysis}

We conducted metaanalyses using the Confidence Profile Method (Eddy et al. 1990). This method uses a hierarchical Bayesian random-effects model and calculates the probability distribution that describes the results expected if a hypothetical additional study, similar to the ones included in the analysis, was performed. By taking into account the heterogeneity of study results, this type of analysis depicts the range of results practitioners could expect should they use the treatment in their own practice settings.

Whereas, the hierarchical random effects model is very robust, there are several potential threats to the 
Table 1. Studies Available for Intent-to-Treat Metaanalyis

\begin{tabular}{|c|c|c|}
\hline Drug & $\begin{array}{l}\text { No. of } \\
\text { Studies }\end{array}$ & Reference by Author(s) \\
\hline \multicolumn{3}{|l|}{ Tricyclics } \\
\hline Amitriptyline & 12 & $\begin{array}{l}\text { Feighner et al. 1979; Goldberg and Finnerty 1980; Reimherr et al. 1990; } \\
\text { Rickels and Case 1982; Rowen et al. 1982; Claghorn et al. 1983; } \\
\text { Hormazabal et al. 1985; Imlah 1985; Rickels et al. 1985; Amsterdam et al. } \\
\text { 1986; Kleiser and Lehmann 1988; Spiker and Kupfer 1988 }\end{array}$ \\
\hline Desipramine & 3 & Stewart et al. 1981, 1983, 1985 \\
\hline Doxepin & 3 & Veith et al. 1982; Jarvik et al. 1983; Rickels et al. 1985 \\
\hline Imipramine & 48 & $\begin{array}{l}\text { Agnew et al. 1961; Rothman et al. 1962; Greenblatt et al. 1964; Schildkraut } \\
\text { et al. 1964; British Medical Research Council 1965; Raskin et al. 1978; } \\
\text { Kellams et al. 1979; Escobar et al. 1980; Feighner 1980; Gerner et al. 1980; } \\
\text { Mann et al. 1981; Rickels et al. 1981; van der Velde 1981; Rickels et al. } \\
\text { 1982a,b; Veith et al. 1982; Feighner et al. 1983a,b; Itil et al. 1983; Jarvik } \\
\text { et al. 1983; Meredith and Feighner 1983a; Meredith et al. 1984; Reimherr } \\
\text { et al. 1984; Liebowitz et al. 1984a,b; Cohn and Wilcox 1985; Dominguez } \\
\text { et al. 1985; Kocsis et al. 1985; Stark and Hardison 1985; Lipman et al. 1986; } \\
\text { Mendels and Schless 1986; Wakelin 1986; Lapierre et al. 1987; Rickels et al. } \\
\text { 1987; Byerley et al. 1988; Liebowitz et al. 1988; Quitkin et al. 1988; Cohn et } \\
\text { al. 1989; Conti and dell'Osso 1989; Elkin et al. 1989; Feighner and Boyer } \\
\text { 1989; Kocsis et al. 1989; Lydiard et al. 1989; Peselow et al. 1989; Quitkin } \\
\text { et al. 1989; Stewart et al. 1989; Versiani et al. 1989; Quitkin et al. } 1990\end{array}$ \\
\hline Nortriptyline & 3 & White et al. 1984; Georgotas et al. 1986; Katz et al, 1990 \\
\hline \multicolumn{3}{|r|}{ 每 } \\
\hline Amoxapine & 1 & Rickels et al. 1981 \\
\hline Bupropion & 4 & $\begin{array}{l}\text { Fabre et al. 1983; Meredith and Feighner 1983b; Feighner et al. 1984; } \\
\text { Lineberry et al. } 1990\end{array}$ \\
\hline Maprotiline & 2 & van der Velde 1981; Edwards and Goldie 1983 \\
\hline Trazodone & 7 & $\begin{array}{l}\text { Kellams et al. 1979; Escobar et al. 1980; Feighner 1980; Goldberg and } \\
\text { Finnerty 1980; Mann et al. 1981; Rickels and Case 1982; Klieser } \\
\text { and Lehmann } 1988\end{array}$ \\
\hline \multicolumn{3}{|r|}{ - } \\
\hline Fluoxetine & 11 & $\begin{array}{l}\text { Reimherr et al. 1984; Cohn and Wilcox 1985; Stark and Hardison 1985; Fieve } \\
\text { et al. 1986; Goodnick et al. 1987; Wernicke et al. 1987a; Fabre and Putnam } \\
\text { 1987 ; Byerley et al. 1988; Muijen et al. 1988; Cohn et al. 1989; Dunlop } \\
\text { et al. } 1990^{a}\end{array}$ \\
\hline Fluvoxamine & 6 & $\begin{array}{l}\text { Itil et al. 1983; Dominguez et al. 1985; Wakelin 1986; Lapierre et al. 1987; } \\
\text { Conti and dell'Osso 1989; Lydiard et al. } 1989\end{array}$ \\
\hline Sertraline & 2 & Peselow et al. 1986; Reimherr et al. 1990 \\
\hline $\begin{array}{l}\text { Paroxetine } \\
\text { MAOIs }\end{array}$ & 2 & Feighner and Boyer 1989; Peselow et al. 1989 \\
\hline Isocarboxacid & 8 & $\begin{array}{l}\text { Ford et al. 1959; Agnew et al. 1961; Joshi 1961; Rothman et al. 1962; Kurland } \\
\text { et al. 1967; Davidson and Turnbull 1983; Giller et al. 1984; Davidson et al. } \\
1988\end{array}$ \\
\hline Phenelzine & 16 & $\begin{array}{l}\text { Agnew et al. 1961; Rees and Davies 1961; Schildkraut et al. 1964; British } \\
\text { Medical Research Council 1965; Robinson et al. 1973; Raskin et al. } \\
\text { 1974; Ravaris et al. 1976; Rowan et al. 1982; Liebowitz et al. 1984a,b; } \\
\text { Georgotas et al. 1986; Quitkin et al. 1988, 1989, 1990; Stewart et al. } \\
\text { 1989; Georgotas et al. } 1986\end{array}$ \\
\hline Tranylcypromine & 3 & Bartholemew 1962; Himmelhoch et al. 1982; White et al. 1984 \\
\hline
\end{tabular}

${ }^{a}$ Included $20 \mathrm{mg}, 40 \mathrm{mg}$ and $60 \mathrm{mg}$ treatment cells.

SSRIs $=$ selective serotonin reuptake inhibitors; MAOIs $=$ monoamine oxidase inhibitors.

internal validity of the metaanalyses. The random effects model accounts for among-study variations and, therefore, accounts for random bias; however, it cannot account for any systematic biases that occurred in all studies. Secondly, for inclusion in the metaanalysis, studies had to present sufficient data to permit calculation of the percentage of the response for each treat- ment, based on the intent-to-treat sample. If studies without sufficient data were fundamentally different from those that were included, summary statistics may be biased. Similarly, a variety of publication biases (e.g., the preferential publication of those studies disproving the null hypothesis) could result in biased summary statistics. 
Table 2. Number of Randomized Placebo Controlled Studies ${ }^{a}$

\begin{tabular}{lcc}
\hline & Outpatient & Inpatient \\
\hline Placebo run-in & $53(41)$ & $14(9)$ \\
No placebo run-in & $\frac{54(33)}{107(74)}$ & $\frac{20(18)}{34(27)}$ \\
Total & 107 \\
\hline
\end{tabular}

a The numbers in parentheses are the number of trials subjected to metaanalysis.

\section{Tabulation of Findings}

We report findings for inpatients and outpatients separately, because attrition rates, as well as placebo and drug response rates, may differ for these two groups. We combined, however, adult and geriatric studies because (1) there is no evidence of differential responses to drug or placebo in published studies to date (Depression Guideline Panel 1993); and, (2) the number of geriatric studies was too few for meaningful independent analyses.

We divided the medications into groups. The tricyclic medications included amitriptyline, desipramine, doxepin, imipramine, nortriptyline, and protriptyline. The heterocyclic group included maprotiline, amoxapine, trazodone, and bupropion. The selective serotonin reuptake inhibitors (SSRIs) included fluoxetine, paroxetine, and sertraline. The MAOIs included isocarboxacid, phenelzine, and tranylcypromine.

\section{RESULTS}

We posed four specific questions to be addressed by the metaanalyses: (1) Does a placebo run-in affect the post-randomization placebo treatment cell response rate?; (2) Does a placebo run-in affect the drug-placebo difference?; (3) Does a placebo run-in affect the drug response rate?; and, (4) Does a post-randomization placebo treatment cell affect drug response rates (with or without a placebo run-in)?

The number of studies available for intent-to-treat metaanalysis in placebo-controlled studies by individual drugs are listed in Table 1 and were as follows: for tricy- clics, amitriptyline $(n=12)$, desipramine $(n=3)$, doxepin $(n=3)$, imipramine $(n=48)$, and nortriptyline $(n=3)$; for heterocyclics, amoxapine $(n=1)$, bupropion $(n=4)$, maprotiline $(n=2)$, and trazodone $(n=7)$; for the SSRIs, fluoxetine ( $n=11)$ (with 17 cells), fluvoxamine $(n=6)$, sertraline $(n=2)$, and paroxetine $(n=$ $2)$; and for the MAOIs, isocarboxacid $(n=8)$, phenelzine $(n=16)$, and tranylcypromine $(n=3)$. Table 2 summarizes the number of studies with and without a placebo run-in by patient status used in the metaanalysis.

Table 3 reveals that whether or not there is a placebo run-in, post-randomization placebo treatment cell response rates are identical. For example, the placebo treatment cell response rate for outpatients with a run-in was $27.8 \% \pm 11.0 \%$ (39 studies), compared to $28.5 \%$ $\pm 8.5 \%$ (33 studies) without a run-in. These two rates are not different from each other. The placebo treatment cell response rates for inpatients were also not different between studies with and without a placebo run-in. Of additional note is the apparent fact that the placebo treatment cell response rates were similar for inpatients and outpatients. Thus, a placebo run-in does not affect the placebo cell response rates.

Table 4 addresses the question of whether or not a placebo run-in affects drug-placebo differences following randomization. For outpatients, the drug-placebo difference for tricyclics was $18.4 \% \pm 5.9 \%$ (32 studies) with a placebo run-in, compared to $21.5 \% \pm$ $8.3 \%$ (21 studies) without a run-in. Similarly for heterocyclics, it was $20.7 \% \pm 18.9 \%$ (3 studies) with a placebo run-in and $14.8 \% \pm 13.4 \%$ (5 studies) without a run-in. For the SSRIs, the drug-placebo difference with a placebo run-in was $20.8 \% \pm 8.5 \%$ (23 studies) versus $27.0 \% \pm 24.2 \%$ (2 studies) without a run-in. Finally, for the MAOIs with a placebo run-in, the difference in probability for drug-placebo was $31.1 \% \pm 18.5 \%(6$ studies) versus $29.9 \% \pm 17.3 \%$ (8 studies) without a run-in. None of these drug-placebo differences in outpatients for individual drugs with and without a placebo run-in were different from each other. The total drugplacebo difference in outpatients for all drugs was $20.6 \%$ $\pm 6.2 \%$ ( 64 studies) with a placebo run-in versus $21.8 \%$ $\pm 7.7 \%$ (36 studies) without a run-in.

For inpatients, the drug-placebo difference for

Table 3. Placebo Treatment Cell Response Rate in RCTs with and without a Placebo Run-In ${ }^{a b}$

\begin{tabular}{llll}
\hline & \multicolumn{1}{c}{ Outpatient } & \multicolumn{1}{c}{ Inpatient } & \multicolumn{1}{c}{ Total } \\
\hline Placebo run-in & $27.8 \%(11.0)[39]$ & $26.2 \%(14.4)[9]$ & $27.6 \%(11.4)[48]$ \\
No placebo run-in & $28.5 \%(8.5)[33]$ & $\frac{31.9 \%(14.8)[14]}{29.6 \%(14.7)[23]}$ & $\frac{29.5 \%(10.6)[47]}{28.2 \%(9.6)[95]}$ \\
\cline { 2 - 3 } & $28.0 \%(8.3)[72]$ & &
\end{tabular}

${ }^{a}$ Numbers in parentheses are standard deviations.

${ }^{b}$ Numbers in brackets are number of cells metaanalyzed. 
Table 4. Drug-Placebo Differences in RCTs with and without a Placebo Run-In ${ }^{a b}$

\begin{tabular}{|c|c|c|c|c|}
\hline & \multicolumn{2}{|c|}{ Outpatient } & \multicolumn{2}{|c|}{ Inpatient } \\
\hline & $\begin{array}{l}\text { Placebo } \\
\text { Run-In }\end{array}$ & $\begin{array}{l}\text { No Placebo } \\
\text { Run-In }\end{array}$ & $\begin{array}{l}\text { Placebo } \\
\text { Run-In }\end{array}$ & $\begin{array}{c}\text { No Placebo } \\
\text { Run-In }\end{array}$ \\
\hline $\begin{array}{l}\text { Tricyclics } \\
\text { Heterocyclics } \\
\text { SSRIs } \\
\text { MAOIs }\end{array}$ & $\begin{array}{l}18.4 \%(5.9)[32] \\
20.7 \%(18.9)[3] \\
20.8 \%(8.5)[23] \\
31.3 \%(18.5)[6]\end{array}$ & $\begin{array}{l}21.5 \%(8.3)[21] \\
14.8 \%(13.4)[5] \\
27.0 \%(24.2)[2] \\
29.9 \%(17.3)[8]\end{array}$ & $\begin{array}{c}25.6 \%(12.5)[8] \\
32.2 \%(13.5)[4] \\
25.5 \%(21.7)[2] \\
\text { NA } \\
\end{array}$ & $\begin{array}{c}33.1 \%(7.9)[6] \\
44.9 \%(10.8)[3] \\
\text { NA } \\
18.4 \%(22.6)[9]\end{array}$ \\
\hline Total & $\overline{20.6 \%(6.2)[64]}$ & $21.8 \%(7.7)[36]$ & $\overline{28.5 \%(10.3)[14]}$ & $35.6 \%(7.7)[18]$ \\
\hline
\end{tabular}

tricyclics was $25.6 \% \pm 12.5 \%$ (8 studies) with a placebo run-in compared to $33.1 \% \pm 7.9 \%$ (6 studies) without a run-in. For heterocyclics with a placebo run-in, the drug-placebo difference was $32.2 \% \pm 13.5 \%$ (4 studies) compared to $44.9 \% \pm 10.8 \%$ (3 studies) without a runin. This finding indicates a tendency toward a higher drug-placebo difference in heterocyclics without a placebo run-in. Similar comparisons were not possible for SSRIs versus MAOIs because there were no inpatient studies of MAOIs with a placebo run-in, and no studies of SSRIs without a placebo run-in. Again, the total drug-placebo difference for all studies with a placebo run-in was $28.5 \% \pm 10.3 \%$ (14 studies) versus $35.6 \% \pm 7.7 \%$ (18 studies). In summary, Table 4 also reveals that the drug-placebo difference is only in the range of $21 \%$ to $35 \%$, although the drug-placebo differences are consistently higher for inpatients than for outpatients. A placebo run-in does not affect drug-placebo differences in outpatients. For inpatients, a placebo runin may actually reduce the drug-placebo difference.

Table 5 addresses the question of whether a placebo run-in affects the post-randomization drug cell response rates. The drug response rates for outpatients in studies with a placebo run-in are not different from drug response rates in studies without a placebo run-in. That is, the presence or absence of a placebo run-in does not affect drug response rates. This finding also appears to apply to inpatients.

Finally, Table 6 addresses the question of whether the presence of a post-randomization placebo treatment cell affects the drug cell response rates. For these analyses, all relevant studies were included whether or not they had a placebo run-in. For outpatients across all medication classes except the SSRIs, the drug response rate is unaffected by whether or not there is a postrandomization placebo treatment cell. Thus, the efficacy rates found in placebo-controlled trials would likely appear to generalize to trials without a placebo arm. For the SSRIs, however, it appears that when there was a placebo treatment arm, the drug response rate was lower than when there was no arm. With the inpatient studies, for each medication group, the presence or absence of a placebo treatment arm generally did not affect the drug response rate, except for the MAOIs, in which case, the inclusion of a placebo treatment arm was associated with a better overall response than when there was no such arm.

Thus, with few exceptions, the presence of a postrandomization placebo treatment cell does not appear to affect drug response rates. For the SSRIs, this finding

Table 5. Drug Response Rates in Studies with and without a Placebo Run-In ${ }^{a b}$

\begin{tabular}{|c|c|c|c|c|}
\hline & \multicolumn{2}{|c|}{ Outpatient } & \multicolumn{2}{|c|}{ Inpatient } \\
\hline & $\begin{array}{l}\text { Placebo } \\
\text { Run-In }\end{array}$ & $\begin{array}{l}\text { No Placebo } \\
\text { Run-In }\end{array}$ & $\begin{array}{l}\text { Placebo } \\
\text { Run-In }\end{array}$ & $\begin{array}{l}\text { No Placebo } \\
\text { Run-In }\end{array}$ \\
\hline Tricyclics & $53.1 \%(6.4)[58]$ & $48.9 \%(5.2)[58]$ & $52.5 \%(11.6)[11]$ & $59.7 \%(15.8)[21]$ \\
\hline Heterocyclics & $58.6 \%(6.6)[12]$ & $58.6 \%(10.0)[22]$ & $49.5 \%(19.8)[8]$ & $51.4 \%(11.9)[8]$ \\
\hline SSRIs & $43.6 \%(5.7)$ [37] & $54.9 \%(8.2)[6]$ & $58.1 \%(9.2)[4]$ & $53.6 \%(12.6)[7]$ \\
\hline MAOIs & $56.2 \%(6.4)[6]$ & $\underline{57.8 \%(6.9)[16]}$ & $\underline{78.6 \%(14.5)[1]}$ & $54.2 \%(10.2)[14]$ \\
\hline Total & $52.4 \%(3.8)[103]$ & $53.9 \%(4.4)[102]$ & $58.1 \%(8.2)[24]$ & $54.3 \%(7.3)[50]$ \\
\hline
\end{tabular}

\footnotetext{
${ }^{a}$ Numbers in parentheses are standard deviations.
}

${ }^{b}$ Numbers in brackets are number of cells metaanalyzed.

SSRIs = selective serotonin reuptake inhibitors; MAOIs = monamine oxidase inhibitors. 
Table 6. Drug Response Rates in Studies with and without a Post-Randomization Placebo Treatment Cell ${ }^{a b}$

\begin{tabular}{|c|c|c|c|c|}
\hline & \multicolumn{2}{|c|}{ Outpatient } & \multicolumn{2}{|c|}{ Inpatient } \\
\hline & $\begin{array}{l}\text { With Placebo } \\
\text { Treatment Cell }\end{array}$ & $\begin{array}{l}\text { Without Placebo } \\
\text { Treatment Cell }\end{array}$ & $\begin{array}{l}\text { With Placebo } \\
\text { Treatment Cell }\end{array}$ & $\begin{array}{c}\text { Without Placebo } \\
\text { Treatment Cell }\end{array}$ \\
\hline $\begin{array}{l}\text { Tricyclics } \\
\text { Heterocyclics } \\
\text { SSRIs } \\
\text { MAOIs }\end{array}$ & $\begin{array}{l}48.9 \%(4.9)[58] \\
57.5 \%(5.3)[8] \\
42.4 \%(4.6)[22] \\
57.4 \%(7.1)[16] \\
\end{array}$ & $\begin{array}{l}53.6 \%(6.9)[58] \\
61.7 \%(11.0)[26] \\
55.3 \%(9.5)[21] \\
61.2 \%(5.4)[6] \\
\end{array}$ & $\begin{array}{l}56.8 \%(16.9)[10] \\
51.8 \%(9.6)[11] \\
58.8 \%(9.2)[3] \\
63.6 \%(17.1)[10]\end{array}$ & $\begin{array}{l}55.0 \%(9.7)[22] \\
50.8 \%(17.5)[5] \\
55.2 \%(11.0)[8] \\
54.7 \%(10.8)[5] \\
\end{array}$ \\
\hline Total & $50.6 \%(3.7)[104]$ & $\overline{58.1 \%(4.6)[111]}$ & $\overline{56.9 \%(7.3)[34]}$ & $\overline{54.7 \%(6.8)[40]}$ \\
\hline
\end{tabular}

${ }^{a}$ Numbers in parentheses are standard deviations.

${ }^{b}$ Numbers in brackets are number of cells metaanalyzed.

SSRIs $=$ selective serotonin reuptake inhibitors; MAOIs $=$ monoamine oxidase inhibitors

was not accounted for by a different response within those studies without a placebo treatment cell that did $55.9 \%( \pm 17.0 \%)$ (15 studies) or didnot $54.9 \%( \pm 8.2 \%)$ (6 studies) have a placebo run-in. One might speculate that the patient sample shifted between premarketing (more likely to include a placebo treatment cell) and post-marketing (less likely to have a placebo treatment cell) studies, or a shift on the rapidity with which dose escalation was recommended (i.e., more rapid escalation premarketing may have led to higher attrition and consequently lower response rates), or the initial symptom severity requirement may have been lowered in post-marketing studies. Alternatively, clinicians may have found that those with atypical features or more chronic forms of depression may preferentially tolerate and/or respond to the SSRIs, as suggested by Reimherr et al.'s (1984) retrospective analyses, that could have led to a more responsive sample with post-marketing studies.

\section{DISCUSSION}

In summary, the previous metaanalyses provide a somewhat surprising, but relatively solid set of findings. A placebo run-in, as compared to no placebo run-in, does not reduce (or increase) the post-randomization placebo response rate, drug response rate, or drugplacebo differences. One can ask, however, about the certainty of these findings. The metaanalyses used are based on a substantial number of studies. The certainty of the percent response rates is reflected in the standard deviations; thus, for the vast majority of analyses, the findings are robust.

We tested the stability of these findings using computer modeling for one part of the analysis. Table 3 shows that the placebo treatment cell response rate is $27.8 \%( \pm 11.0 \%)$ for 39 studies of outpatients with a placebo run-in, and $28.5 \%$ ( $\pm 8.5 \%$ ) for 33 studies without a placebo run-in. In order to create a post-randomization placebo treatment cell response rate of $24.6 \%$
$( \pm 11.2 \%)$ in RCTs with a placebo run-in (i.e., $3.2 \%$ lower than the $27.8 \%$ estimated in the current 39 studies), an additional 39 similarly sized studies are needed that have a placebo response rate of only $20.0 \%( \pm 10.9 \%)$.

Why might a placebo run-in generally fail to affect placebo response rates or drug-placebo differences post randomization? First, studies without a placebo run-in rarely enter patients immediately at the first visit. There is often a screening visit at which informed consent is obtained, and ratings, and laboratory screening tests are conducted. Patients, even on no medication, return 3 days to 10 days later, learn that their laboratory tests are normal, receive another severity rating, and are randomized. Sometimes a third visit, spaced only a few days after the screen visit, is needed. For example, patients on medications are discontinued, which may require an additional one to two visits. A nearly identical procedure is followed when there is a placebo run-in, as the pill placebo may be given between screen (first visit) and baseline (time of randomization). Furthermore, the intensity and/or nature of patient education/adherence counseling has generally increased over the years with or without a placebo run-in.

It is entirely reasonable to assume that the process of consenting, being educated, being screened for eligibility, and the subsequent post-screen visits even without a pill placebo are just as effective as a pill placebo in identifying placebo run-in "responders." That is, the pill placebo may add little except cost in identifying run-in "responders."

The findings in Table 4 deserve comment. There appears to be a slight difference between the effects of a placebo run-in versus no run-in on drug-placebo differences found with inpatients as opposed to outpatients. For inpatients, there is a tendency for studies without a run-in to be associated with a somewhat higher drug-placebo difference; however, the number of studies in each drug group is modest, so caution is warranted. On the other hand, one might speculate that for inpatients, the lack of a placebo run-in may induce investigators to enroll more acutely (severely) ill sub- 
jects who in turn more specifically benefit from drug as opposed to placebo, thereby increasing drug-placebo differences.

In outpatients, the presence or absence of a placebo run-in generally appears to make no difference. With SSRIs, a $27.0 \%$ drug-placebo difference without a runin, versus a $20.8 \%$ difference with a run-in is not meaningful given the high standard deviations and the availability of only two studies in the former group, although the difference is consistent with Reimherr et al. (1984).

Secondly, in outpatients, the metaanalyses suggest that the presence of a post-randomization placebo treatment arm generally does not significantly affect drug response rates, except for the SSRIs, in which case, the absence of a placebo arm is associated with a slight increase in the response rate. This finding could result from patients with greater Axis II or more chronic depressions who would decline a placebo-controlled study versus entering studies without a placebo arm, if the SSRIs were particularly beneficial for this patient group as compared to the other antidepressant classes. The latter notion is supported by Reimherr and colleagues (1984).

The overall slightly greater drug response rates in outpatients for all drugs (Table 6) in trials without,opposed to those with, a post-randomization placebo treatment cell, that are not robust, are seemingly consistent. This tendency could result from subject selection (i.e., less severely or chronically ill subjects being more likely included in post-marketing, nonplacebo controlled trials). Alternatively, it could result from investigator and participant knowledge of the lack of a placebo treatment cell, that leads to both expecting a greater response, thereby slightly inflating ratings in trials without a placebo arm, or conversely, slightly underestimating responses in placebo-controlled trials. However, because a similar pattern is not seen with inpatient trials, the case for patient/investigator bias is not strong.

For inpatients, the MAOIs with a placebo treatment cell were associated with greater efficacy than MAOIs without a placebo cell. This finding is consistent with the notions that MAOIs may be more effective in the less severely ill (e.g., outpatients versus inpatients) (Depression Guideline Panel 1993, pp. 50-51), combined with the idea that less severely ill inpatients may be more likely to agree to a placebo-controlled trial than the more severely ill may agree to.

Whether or not patients who drop their HRS-D score by a predetermined degree or percent should be excluded (whether with or without a placebo run-in) cannot be addressed by this report. Logic, clinical practice, and the need for clinical relevance and generalizability would argue that if there are sufficient symptoms at randomization to indicate drug treatment, the pa- tient should be entered. That is, the raw HRS-D score at the time of randomization would seem to be the primary variable to dictate inclusion or exclusion. In addition, prior reports are consistent with the notion that patients who "respond" to a one-week placebo run-in are clinically dissimilar to those who respond to a multiweek post-randomization placebo treatment arm (Rabkin et al. 1987). Reimherr and coworkers (1989) suggest that the percent drop rule may not be valid and may even slightly reduce drug-placebo differences.

Finally, measurement itself may present a problem in some patients. For example, if a patient initially scores a 22 on the HRS-D, but at randomization drops to 17 , a $20 \%$ drop has occurred, and the patient is excluded. However, the reliability even of the 17-item HRS-D is on the order of \pm 2 in this range. Thus, a 22 is really a score of between 20 and 24 . A 17 is really a score of between 15 and 19. Thus, at least in some patients, a clinically meaningless "drop" can lead to subject exclusion.

Conversely, Quitkin and coworkers (personal communication, June 1994) found in a retrospective analysis combining several trials that those with minimal severity reductions in the prerandomization pill-placebo run-in, had a higher response rate to either placebo or drug than those with a greater drop (although patients with a clinically significant drop were excluded). However, the drug-placebo differences in these two groups may not actually change.

From the clinical perspective, there are several reassuring findings that include: (1) drug response rates with or without a placebo run-in are the same, (2) whether or not there is a placebo treatment arm, seems not to affect drug response (except a better response may be present for SSRIs) when there is no such arm, and (3) the drug class involved does not change the above findings. To estimate effects in the "real world" of clinical practice (effectiveness) from RCTs with/without placebo run-ins or placebo cells, these data suggest that these design features do not profoundly affect overall efficacy. That is, if practitioners follow the other procedures (e.g., weekly visits, measuring outcome, dose adjustments), an equal or better outcome for similar kinds of patients treated with the medication in question can be anticipated.

From a research perspective, however, these findings raise serious questions as to the value of a singleblind pill placebo run-in to exclude patients in efficacy trials. As with any retrospective analysis, especially when combining many studies, one cannot be completely convinced of these results. The only sure test would be an RCT in which half the patients received a single-blind placebo run-in, whereas the other half did not. This type of study would determine if these two different procedures, each designed to exclude patients under different conditions, would perform 
equally, excluding the same types and numbers of subjects.

In summary, these findings lend no support to the need for a pill placebo run-in, as compared to a multivisit run-in without a pill placebo. Further, empirical studies of the utility of the percent drop rule often used during the run-in period are needed.

\section{ACKNOWLEDGMENTS}

The authors appreciate the efforts of Michael E. Thase, M.D., for providing the literature review on MAOIs, the consultation of David Schriger, M.D., M.P.H., regarding the metaanalysis, the secretarial support of Fast Word Inc. of Dallas and David Savage, and the administrative support of Kenneth Z. Altshuler, M.D., Stanton Sharp Distinguished Chair and Chairman, Department of Psychiatry, UT Southwestern Medical Center. Parts of this paper were presented at the 33rd annual NCDEU meeting, June 1-4, 1993 in Boca Raton, Florida. A listing of the specific studies in each summary table are available upon written request to Dr. Trivedi.

This work was supported in part by a Young Investigator Award to Dr. Trivedi from the National Alliance for Research on Schizophrenia and Affective Disorders (NARSAD), by a National Institute of Mental Health Center Grant (MH41115) to the Department of Psychiatry, UT Southwestern Medical Center, and by the AHCPR as part of its clinical practice guideline development process under Forum contract \#282-910700 and/or \#282-920069.

\section{REFERENCES}

Agnew PC, Baran ID, Klapman HJ, Reid FT, Stern JJ, Slutske RH (1961): A clinical evaluation of four antidepressant drugs (Nardil, Tofanil, Marplan, and Deprol). Am J Psychiatry 118:160-162

Amsterdam JD, Case WG, Csanalosi E, Singer M, Rickels K (1986): A double-blind comparative trial of zimelidine, amitriptyline, and placebo in patients with mixed anxiety and depression. Pharmacopsychiatry 19:115-119

Bartholemew AA (1962): An evaluation of tranylcypromine (Parnate) in the treatment of depression. Med J Aust 49:655-662

British Medical Research Council (1965): Clinical trial of the treatment of depressive illness. Br Med J 1:881-886

Byerley WF, Reimherr FW, Wood DR, Grosser BI (1988): Fluoxetine, a selective serotonin uptake inhibitor, for the treatment of outpatients with major depression. J Clin Psychopharmacol 8:112-115

Claghorn J, Gershon S, Goldstein BJ, Behmetz S, Bush DF, Huitfeldt B (1983): A double-blind evaluation of zimelidine in comparison to placebo and amitriptyline in patients with major depressive disorder. Prog Neuropsychopharmacol Biol Psychiatry 7:367-382

Cohn JB, Collins G, Ashbrook E, Wernicke JF (1989): A comparison of fluoxetine imipramine and placebo in patients with bipolar depressive disorder. Int Clin Psychopharmacol 4:313-322

Cohn JB, Wilcox C (1985): A comparison of fluoxetine, im- ipramine, and placebo in patients with major depressive disorder. J Clin Psychiatry 46:26-31

Conti L, dell'Osso L (1989): Clinical predictors of response to fluvoxamine, imipramine, and placebo. New Trends Exp Clin Psychiatry 5:221-229

Davidson JRT, Giller EL, Zisook S, Overall JE (1988): An efficacy study of isocarboxazid and placebo in depression, and its relationship to depressive nosology. Arch Gen Psychiatry 45:120-127

Davidson J, Turnbull C (1983): Isocarboxazid: Efficacy and tolerance. J Affective Disord 5:183-189

Depression Guideline Panel. Clinical Practice Guideline. Depression in Primary Care: Volume 2. Treatment of Major Depression. Rockville, MD. U.S. Department of Health and Human Services. Public Health Service. Agency for Health Care Policy and Research. AHCRP Publication No. 93-0551, 1993

Depression Guideline Panel. Clinical Practice Guideline. Depression in Primary Care: Detection, Diagnosis and Treatment. Technical Manual. Rockville, MD. U.S. Department of Health and Human Services. Public Health Service. Agency for Health Care Policy and Research (In Press)

Dominguez RA, Goldstein BJ, Jacobson AF, Steinbook RM (1985): A double-blind placebo-controlled study of fluvoxamine and imipramine in depression. J Clin Psychiatry 46:84-87

Dunlop SR, Dornself BE, Wernicke JF, Potvin JH (1990): Pattern analysis shows beneficial effect of fluoxetine treatment in mild depression. Psychopharmacol Bull 26: 173-180

Eddy DM, Hasselblad V, Schacter R (1990): A Bayesian method for synthesizing evidence: The confidence profile method. Int J Technol Assess Health Care 6:31-35

Edwards JG, Goldie A (1983): Placebo-controlled trial of mianserin and maprotiline in primary depressive illness: A preliminary report. Br J Clin Pharmacol 15 (Suppl 2):239S-248S

Elkin I, Shea TM, Watkins JT, Imber SD, Sotsky SM, Collins JF, Glass DR, Pilkonis PA, Leber WR, Docherty JP, et al. (1989): National Institute of Mental Health Treatment of Depression Collaborative Research Program: General effectiveness of treatments. Arch Gen Psychiatry 46: 971-982

Escobar JI, Gomez J, Constain C, Rey J, Santacruz H (1980): Controlled clinical trial with trazodone, a novel antidepressant: A South American experience. J Clin Pharmacol 20:124-130

Fabre LF, Brodie H, Garver D, Zung W (1983): A multicenter evaluation of buproprion versus placebo in hospitalized depressed patients. J Clin Psychiatry 44:89-94

Fabre LF, Putman HP III (1987): A fixed-dose clinical trial of fluoxetine in outpatients with major depression. J Clin Psychiatry 48:406-408

Fairchild CJ, Rush AJ, Vasavada N, Giles DE, Khatami M (1986): Which depressions respond to placebo? Psychiatry Res 18:217-226

Feighner JP, Brauzer B, Gelenberg AJ, Gomez E, Kiev A, Kurland ML, Weiss BL (1979): A placebo-controlled multicenter trial of limbitrol versus its components (amitriptyline and chlordizepoxide) in the symptomatic treatment of depressive illness. Psychopharmacology 61:217-225 
Feighner JP, Boyer WF (1989): Paroxetine in the treatment of depression: A comparison with imipramine and placebo. Acta Psychiatr Scand Suppl 350:125-129

Feighner JP, Aden GC, Fabre LF, Rickels K, Smith WT (1983a): Comparison of alprazolam, imipramine, and placebo in the treatment of depression. JAMA 10:3057-3064

Feighner JP, Meredith CH, Frost NR, Chammas S, Hendrickson G (1993b): A double-blind comparison of alprazolam versus imipramine and placebo in the treatment of major depressive disorder. Acta Psychiatr Scand 68: 223-233

Feighner JP, Meredith CH, Stern W, Hendrickson G, Miller L (1984): A Double-blind study of bupropion and placebo in depression. Am J Psychiatry 141:525-529

Feighner JP (1980): Trazodone, a triazolopyridine derivative, in primary depressive disorder. J Clin Psychiatry 41: 250-255

Fieve RR, Goodnick PJ, Peselow ED, Barouche F, Schlegel A (1986): Pattern analysis of antidepressant response to fluoxetine. J Clin Psychiatry 47:560-562

Ford RB, Branham HE, Cleckley JJ (1959): Isocarboxazid: A new antidepressant drug. Clin Med 6:1559-1561

Georgotas A, Stokes P, McCue RE, Dubow A, Welkowitz J, Friedman E, Fanelli C, Chang I, Cooper TB (1986): The usefulness of DST in predicting response to antidepressant: A placebo-controlled study. J Affective Disord 11: 21-28

Gerner R, Estabrook W, Steuer J, Jarvik L (1980): Treatment of geriatric depression with trazodone, imipramine, and placebo: A double-blind study. J Clin Psychiatry 41: 216-220

Giller E Jr, Bialos O, Harkness L, Riddle M (1984): Assessing treatment response to the monoamine oxidase inhibitor isocarboxazid. J Clin Psychiatry 45:44-48

Goldberg HL, Finnerty RJ (1980): Trazodone in the treatment of neurotic depression. J Clin Psychiatry 41:430-434

Goodnick PJ, Fieve RR, Peselow ED, Barouche F, Schlegel A (1987): Double-blind treatment of major depression with fluoxetine: use of pattern analysis and relation of HRS-D score to CGI change. Psychopharmacol Bull 23:162-163

Greenblatt M, Grosser GH, Wechsler H (1964): Differential response of hospitalized depressed patients to stomatic therapy. Am J Psychiatry 120:935-943

Guy W (1976): ECDEU assessment manual for psychopharmacology. Washington, DC: Superintendent of Documents, U.S. Government Printing Office, U.S. Department of Health, Education, and Welfare Publication, Washington, DC, No. 76-338

Hamilton M (1960): A rating scale for depression. J Neurol Neurosurg Psychiatry 23:56-62

Himmelhoch JM, Fuchs CZ, Symons BJ (1982): A double-blind study of tranylcypromine treatment of major anergic depression. J Nerv Ment Dis 170:628-634

Hormazabal L, Omer LM, Ismail S (1985): Cianopramine and amitriptyline in the treatment of depressed patients - a placebo-controlled study. Psychopharmacology (Berlin) 86:205-208

Imlah NW (1985): An evaluation of alprazolam in the treatment of reactive or neurotic (secondary) depression. $\mathrm{Br}$ J Psychiatry 146:515-519
Itil TM, Shrivastava RK, Mukherjee S, Coleman BS, Michael ST (1983): A double-blind placebo-controlled study of fluvoxamine and imipramine in outpatients with primary depression. Br J Clin Pharmacol 15 (Suppl 3): 433S-438S

Jarvik LF, Read SL, Mintz J, Neshkes RE (1983): Pretreatment orthostatic hypotension in geriatric depression: Predictor of response to imipramine and doxepin. J Clin Psychopharmacol 3:368-372

Joshi VG (1961): Controlled clinical trials in isocarboxazid (Marplan) in hospital psychiatry. J Ment Sci 107:567-571

Katz IR, Simpson GM, Curlik SM, Parmelee PA, Muhly C (1990): Pharmacologic treatment of major depression for elderly patients in residential care settings. J Clin Psychiatry 51 (Suppl):41-47

Kellams JJ, Klapper MH, Small JG (1979): Trazodone, a new antidepressant: Efficacy and safety in endogenous depression. J Clin Psychiatry 40:390-395

Klieser E, Lehmann E (1968): Experimental comparison between the effect of standardized trazodone-amitriptyline and placebo treatment in vitalized depressive patients. Psychopharmacology (Berlin) 95 (Suppl):S3-5

Kocsis JH, Frances A, Mann JJ, Sweeney J, Voss C, Mason B, Brown RP (1985): Imipramine for treatment of chronic depression. Psychopharmacol Bull 21:698-700

Kocsis JH, Mason BJ, Frances AJ, Sweeney J, Mann JJ, Marin D (1989): Prediction of response of chronic depression to imipramine. J Affective Disord 17:255-260

Kurland AA, Destounis N, Shaffer JW, Pinto A (1967): A critical study of isocarboxazid (Marplan) in the treatment of depressed patients. J Nerv Ment Disease 145:292-305

Lapierre YD, Browne M, Horn E, Oyewumi LK, Sarantidis D, Roberts N, Badoe K, Tessier P (1987): Treatment of major affective disorder with fluvoxamine. J Clin Psychiatry 48:65-68

Liebowitz MR, Quitkin FM, Stewart JW, McGrath PJ, Harrison WM, Markowitz JS, Rabkin JG, Tricamo E, Goetz DM, Klein DF (1988): Antidepressant specificity in atypical depression. Arch Gen Psychiatry 45:129-137

Liebowitz MR, Quitkin FM, Stewart JW, McGrath PJ, Harrison W, Rabkin J, Tricamo E, Markowitz JS, Klein DF (1984a): Phenelzine versus imipramine in atypical depression. Arch Gen Psychiatry 41:669-677

Liebowitz MR, Quitkin FM, Stewart JW, McGrath PJ, Harrison W, Rabkin JG, Tricamo E, Markowitz JS, Klein DF (1984b): Psychopharmacologic validation of atypical depression. J Clin Psychiatry 45:22-25

Lineberry C, Johnston J, Raymond R, Samara B, Feighner J, Harto N, Granacher R, Weisler R, Carman J, Boyer W (1990): A fixed-dose (300 mg) efficacy study of bupropion and placebo in depressed outpatients. J Clin Psychiatry 51:194-199

Lipman RS, Covi L, Rickels K, McNair DM, Downing R, Kahn RJ, Lasseter VK, Faden V (1986): Imipramine and chlordiazepoxide in depressive and anxiety disorders. I. Efficacy in depressed outpatients. Arch Gen Psychiatry 43:68-77

Lydiard RB, Laird LK, Morton WA Jr, Steele TE, Kellner C, Laraia MT, Ballenger JC (1989): Fluvoxamine, imipramine, and placebo in the treatment of depressed outpatients: Effects on depression. Psychopharmacol Bull 25:68-70 
Mann JJ, Georgotas A, Newton R, Gershon S (1981): A controlled study of trazodone, imipramine, and placebo in outpatients with endogenous depression. J Clin Psychopharmacol 1:75-80

Mendels J, Schless AP (1986): Comparative efficacy of alprazolam, imipramine, and placebo administered once a day in treating depressed patients. J Clin Psychiatry 47: 357-361

Meredith CH, Feighner JP (1983a): A double-blind, controlled evaluation of zimeldine, imipramine, and placebo in patients with primary affective disorders. Acta Psychiatr Scand 308 (Suppl):70-79

Meredith CH, Feighner JP (1983b): The use of bupropion in hospitalized depressed patients. J Clin Psychiatry 44 (5; Sec 2):85-87

Meredith CH, Feighner JP, Hendrickson G (1984): A doubleblind comparative evaluation of the efficacy and safety of nomifensine, imipramine, and placebo in depressed geriatric outpatients. J Clin Psychiatry 45 (4 Pt 2):73-77

Muijen M, Roy D, Silverstone T, Mehmet A, Christie M (1988): A comparative clinical trial of fluoxetine, mianserin, and placebo in depressed outpatients. Acta Psychiatr Scand 78:384-390

Peselow ED, Lautin A, Wolkin A, Rohrs C, Novatt A, Siekierski J, RotrosenJ(1986): The dexamethasone suppression test and response to placebo. J Clin Psychopharmacol 6:286-291

Peselow ED, Stanley M, Filippi AM, Barouche F, Goodnick $P$, Fieve RR (1989): The predictive value of the dexamethasone suppression test: A placebo-controlled study. $\mathrm{Br}$ J Psychiatry 155:667-672

Prien RF, Levine J (1984): Research and methodological issues for evaluating the therapeutic effectiveness of antidepressant drugs. Psychopharmacol Bull 20:250-257

Quitkin FM, McGrath PJ, Stewart JW, Harrison WM, Tricamo E, Wager SG, Ocepek-Welikson K, NunesE, RabkinJG, Klein DF (1990): Atypical depression, panic attacks, and response to imipramine and phenelzine: A replication. Arch Gen Psychiatry 47:935-941

Quitkin FM, McGrath PJ, Stewart JW, Harrison W, Wager SG, Nunes E, Rabkin JG, Tricamo E, Markowitz J, Klein DF (1989): Phenelzine and imipramine in mood reactive depressives: Further delineation of the syndrome of atypical depression. Arch Gen Psychiatry 46:787-793

Quitkin FM, Stewart JW, McGrath PJ, Liebowitz MR, Harrison WM, Tricamo E, Klein DF, Rabkin JG, Markowitz JS, Wager SG (1988): Phenelzine versus imipramine in the treatment of probable atypical depression: Defining syndrome boundaries of selective MAOI responders. Am J Psychiatry 145:306-311

Rabkin JG, McGrath PJ, Stewart JW, Harrison W, Markowitz JS, Quitkin FM (1986): Follow-up of patients who improved during placebo. J Clin Psychopharmacol 6:274-278

Rabkin JG, Stewart JW, McGrath PJ, MarkowitzJS, Harrison W, Quitkin FM (1987): Baseline characteristics of 10-day placebo washout responders in antidepressant trials. Psychiatry Res 21:9-22

Raskin A, Boothe H, Reatig N, Schulterbrandt JG (1978): Initial response to drugs in depressive illness and psychiatric and community adjustment a year later. Psychol Med 8:71-79
Raskin A, Schulterbrandt JG, Reatig N, Crook TH, Odle D (1974): Depression subtypes and response to phenelzine, diazepam, and a placebo. Arch Gen Psychiatry 30:66-75

Ravaris CL, Nies A, Robinson DS, Ives JO, Lamborn KR, Korson L (1976): A multiple-dose controlled study of phenelzine in depression-anxiety states. Arch Gen Psychiatry 33:347-350

Rees L, Davies B (1961): A controlled trial of phenelzine ("Nardil") in the treatment of severe depressive illness. J Ment Sciences 107:560-566

Reimherr FW, Chouinard G, Cohn CK, Cole JO, Itil TM, LaPierre YD, Masco HL, Mendels J (1990): Antidepressant efficacy of sertraline: A double-blind, placebo- and amitriptyline-controlled, multicenter comparison study in outpatients with major depression. J Clin Psychiatry. 51 (Suppl B):18-27

Reimherr FW, Ward MF, Byerley WF (1989): The introductory placebo washout: A retrospective evaluation. Psychiatry Res 30:191-199

Reimherr FW, Wood DR, Byerley B, Brainard J, Grosser BI (1984): Characteristics of responders to fluoxetine. Psychopharmacol Bull 20:70-72

Rickels K, Case WG (1982): Trazodone in depressed outpatients. Am J Psychiatry 139:803-806

Rickels K, Case WG, Werblowsky J, Csanalosi I, Schless A, Weise CC (1981): Amoxapine and imipramine in the treatment of depressed outpatients: A controlled study. Am J Psychiatry 138:20-24

Rickels K, Cohen D, Csanalosi I, Harris H, Koepke H, Werblowsky J (1982a): Alprazolam and imipramine in depressed outpatients: A controlled study. Curr Ther Res 32:157-164

Rickels K, Chung HR, Csanalosi IB, Hurowitz AM, London J, Wiseman K, Kaplan M, Amsterdam JD (1987): Alprazolam, diazepam, imipramine, and placebo in outpatients with major depression. Arch Gen Psychiatry 44:862-866

Rickels K, Lipman R, Raab E (1966): Previous medication, duration of illness, and placebo response. J Nerv Ment Dis 142:548-554

Rickels K, Feighner JP, Smith WT (1985): Alprazolam, amitriptyline, doxepin, and placebo in the treatment of depression. Arch Gen Psychiatry 42:134-141

Rickels K, Weise CC, Sandler K, Schless A, Zal M, Norstad N (1982b): Nomifensine, imipramine, and placebo in depressed outpatients. Int Pharmacopsychiatry 17 (Suppl 1):73-88

Robinson DS, Nies A, Ravaris CL, Lamborn KR (1973): The monoamine oxidase inhibitor, phenelzine, in the treatment of depressive-anxiety states: A controlled clinical trial. Arch Gen Psychiatry 29:407-13

Rothman R, Grayson H, Ferguson J (1962): A comparative investigation of isocarboxazid and imipramine in depressive syndromes: A second report. J Neuropsychiatry 3:234-240

Rowan PR, Paykel ES, Parker RR (1982): Phenelzine and amitriptyline: Effects on symptoms of neurotic depression. Br J Psychiatry 140:475-483

Schildkraut JJ, Klerman GL, Hammond R, Friend DG (1964): Excretion of 3-methoxy-4-hydroxy-mandelic acid (VMA) in depressed patients treated with antidepressant drugs. J Psychiatr Res 2:257-266 
Spiker DG, Kupfer DJ (1988): Placebo response rates in psychotic and nonpsychotic depression. J Affective Disord 14:21-23

Stark P, Hardison CD (1985): A review of multicenter controlled studies of fluoxetine versus imipramine and placebo in outpatients with major depressive disorder. J Clin Psychiatry 46: (3 Pt 2):53-58

Stewart JW, McGrath PJ, Quitkin FM, Harrison W, Markowitz J, Wager S, Leibowitz MR (1989): Relevance of DMS-III depressive subtype and chronicity of antidepressant efficacy in atypical depression: Differential response to phenelzine, imipramine, and placebo. Arch Gen Psychiatry 46:1080-1087

Stewart JW, Quitkin F, Liebowitz MR, McGrath PJ, Klein DF (1981): Efficacy of desipramine in mildly depressed patients: a double-blind, placebo-controlled trial [proceedings]. Psychopharmacol Bull 17:136-138

Stewart JW, McGrath PJ, Liebowitz MR, Harrison W, Quitkin F, Rabkin JG (1985): Treatment outcome validation of DSM-III depressive subtypes: Clinical usefulness in outpatients with mild to moderate depression. Arch Gen Psychiatry 42:1148-1153

Stewart JW, Quitkin FM, Liebowitz MR, McGrath PJ, Harrison WM, Klein DF (1983): Efficacy of desipramine in depressed outpatients: Response according to research diagnosis criteria diagnoses and severity of illness. Arch Gen Psychiatry 40:202-207

van de Velde CD (1981): Maprotiline versus imipramine and placebo in neurotic depression. J Clin Psychiatry 42: 138-141

Veith RC, Raskind MA, Caldwell JH, Barnes RF, Gumbrecht G, Ritchie JL (1982): Cardiovascular effects of tricyclic antidepressants in depressed patients with chronic heart disease. N Engl J Med 306:954-959

Versiani M, Oggero U, Alterwain P, Capponi R, Dajas F, Heinze-Martin G, Marquez CA, Poleo MA, RiveroAlmanzor LE, Rossel L, et al. (1989): A double-blind comparative trial of moclobemide versus imipramine and placebo in major depressive episodes. Br J Psychiatry 6 (Suppl):72-77

Wakel in JS (1986): Fluvoxamine in the treatment of the older depressed patient; double-blind, placebo-controlled data. Int Clin Psychopharmacol 1:221-230

Wernicke JF, Dunlop SR,Dornseif BE, Zerbe RL (1987): Fixeddose fluoxetine therapy for depression. Psychopharmacol Bull 23:164-168

White K, Razani J, Cadow B, Gelfand R, Palmer R, Simpson G, Sloane RB (1984): Tranylcypromine versus nortriptyline versus placebo in depressed outpatients: A controlled trial. Psychopharmacology 82:258-262 